\title{
DEVELOPMENT OF PALM-BASED VANASPATI (VEGETABLE GHEE): EFFECTS OF CRYSTALLISATION PROCEDURES ON THE PRODUCT TEXTURE
}

\author{
RAFIDAH ABD HAMID*; SIVARUBY KANAGARATNAM*; NORAZURA AILA MOHD HASSIM*; \\ NUR HAQIM ISMAIL*; WAN ROSNANI AWG ISA* and NOOR LIDA HABI MAT DIAN*
}

\begin{abstract}
Trans free vanaspati (vegetable ghee) formulated using a blend of refined, bleached and deodourised (RBD) palm stearin with iodine value of 30 (POs IV30) and palm olein with iodine value of 58 (POo IV58) in 40:60 $w / w$ ratio was produced. The effect of mixing procedure on the crystallisation of the blend was investigated. VC-1 treatment which involved mixing of POs IV30 at $24^{\circ} \mathrm{C}$ into POo IV58 at $65^{\circ} \mathrm{C}$ and mixing the blend to a complete melt at room temperature followed by tempering at $25^{\circ} \mathrm{C}$ produced a granulated vanaspati with spherical or granular shape crystals. VC-2 treatment which involved the mixing of POs IV30 at $55^{\circ} \mathrm{C}$ into POo IV58 at $24^{\circ} \mathrm{C}$ and mixing the blend to a complete melt at room temperature followed by tempering at $25^{\circ} \mathrm{C}$ produced small crystals which is suitable for the production of smooth textured vanaspati. Vanaspati produced using VC-3 treatment which involved the mixing of POs IV30 at $24^{\circ} \mathrm{C}$ into POo IV58 at $65^{\circ} \mathrm{C}$ but was not mixed to a complete melt, followed by tempering at $25^{\circ} \mathrm{C}$ produced small crystals and loosely packed structure which led to the formation of a slightly grainy textured vanaspati. Thus, a consistent and homogenous grainy textured vanaspati could be produced under controlled conditions using treatment VC-1 and this will be able to resolve the problem of inconsistency of texture in 100\% palm-based grainy vanaspati. Grainy vanaspati is preferred by consumers in India and Pakistan where the demand of vanaspati is very high.
\end{abstract}

Keywords: vegetable ghee, vanaspati, palm stearin, palm olein, crystallisation procedure, smooth texture, granular texture.

Received: 29 June 2020; Accepted: 14 September 2020; Published online: 24 December 2020.

\section{INTRODUCTION}

Vanaspati, also known as vegetable ghee, is an all-purpose fat widely used in the Indo-Pakistan subcontinent and Middle Eastern countries. It is used for cooking purposes in different domestic and commercial places (Ahmad et al., 2006). In India, the consumption of edible oils and vanaspati is comparatively high compared to other countries with a production of about 1.2 million tonnes annually (Vanaspati ghee

\footnotetext{
Malaysian Palm Oil Board,

6 Persiaran Institusi, Bandar Baru Bangi,

43000 Kajang, Selangor, Malaysia.

E-mail: rafidah@mpob.gov.my
}

industry, 2020). Meanwhile, vanaspati has emerged as one of the most essential ingredients of human diet in Pakistan (Ahmad et al., 2006) and Iran (Farmani et al., 2007).

Originally, vanaspati was developed as an alternative to the traditional ghee made from butter fat. Vanaspati is required to have a coarse granular structure at ambient temperature, with crystal required to melt at $37^{\circ} \mathrm{C}-39^{\circ} \mathrm{C}$ (Nor Aini et al., 1997). The texture preference of this product varies for different consumers. In India and Pakistan, graininess is a required criterion. Unlike the Indian counterparts who prefer their vanaspati to be grainy, yet dry and crumbly, Pakistani consumers prefer grainy crystals among liquid oil (Siew, 2011). 
Initially, fully or partially hydrogenated fats have been found to be the most suitable and widely used fats in the production of vanaspati. However, hydrogenated fats contain undesirable and health threatening trans fatty acids. Palm oil $(\mathrm{PO})$ is the most promising material in terms of price, availability and functionality for vanaspati. PO which has similar physical characteristics such as melting points, melting profile and semi-solid consistency at ambient temperature to butter fat has been widely used in the making of vanaspati. Palm stearin (POs) which is the solid fraction of PO, can also be used for making vanaspati. Although naturally $\mathrm{PO}$ and POs do not develop the desired granular appearance, vanaspati of satisfactory granular consistency can be obtained by employing interesterification (IE) on the palm-based vanaspati oil blends (Kheiri and Oh, 1983; Nor Aini et al., 1997; Siew, 2011). Furthermore, more PO fractions can be incorporated in vanaspati with IE process (Nor Aini and Noor Lida, 2005). Nor Aini et al. (1997; 1999) and Nor Aini and Noor Lida (2005) reported that trans free vanaspati having characteristics similar to those of hydrogenated vanaspati can be produced using blends of POs and liquid oils such as rapeseed, soyabean and sunflower oils, either by direct blending or by employing IE. When PO products are used in high amounts, it can facilitate separation of liquid and solid phases through slow cooling. Phase separation characteristic is associated with melting points of various triacylglycerols (TAG) present in PO. This property of $\mathrm{PO}$ can assist production of vanaspati which targets grainy crystals among liquid oil (Sivaruby and Noor Lida, 2007).

Besides blending formulations and ingredients, processing conditions also play a very important role because they have great capability to determine the properties of vanaspati. Processing conditions can affect the physical properties of the vanaspati including its appearance, texture, and crystallisation behaviour (Farmani and Gholitabar, 2015). In some countries, especially in India, Pakistan and Bangladesh, granularity is considered as an important criterion of quality and purity of vanaspati. To achieve granular texture, the oil/blend is cooled slowly in a cold room maintained at $15^{\circ} \mathrm{C}$ with adequate cold air circulation (Kheiri, 1985). On slow cooling, $\beta^{\prime}$ crystal would first form followed by the $\alpha$-crystal surrounding the $\beta^{\prime}$ crystal that acts as nuclei for crystallisation (Blaurock, 1999; Nor Aini et al., 2010). Products with smooth texture are obtained by rapidly cooled the oil/blend on a scraped-surface heat exchanger (Kheiri, 1985; Noor Lida et al., 2017). Hot oil that is rapidly cooled to a temperature below melting point would most probably crystallise in $\alpha$ form followed by the formation of $\beta^{\prime}$ and $\beta$ crystals (Blaurock 1999; Nor Aini et al., 2010). Besides various temperature conditions, emulsifier with different hydrophobic properties would also affect fat properties by accelerating or retarding crystallisation and polymorphic transformation (Garti 2002; Miskandar et al., 2002a; 2002b).

The dynamic slow crystallisation will promote crystal formation in spherical shape, while dynamic fast crystallisation, produces needle shaped small crystals (Martini et al., 2002; Miskandar et al., 2004). Slow agitation will produce crystal with denser crystal structure, while higher agitation rate results in the formation of many small crystals mainly transparent, with lower amount of solid in each crystal (Herrera and Hartel, 2000). Crystallisation without agitation will cause the crystals to be densely arranged and bigger in size (Martini et al., 2002).

Although palm-based oils are widely used in the making of vanaspati, information on the effects of manufacturing procedures on the physical characteristics of palm-based vanaspati are scarce. This article reports the effect of crystallisation procedure on the blend of POs with iodine value of 30 (POs IV30) and palm olein with iodine value of 58 (POo IV58) at 40:60 w/w ratio in a vessel type crystalliser on the texture of vanaspati made of the said blend.

\section{MATERIALS AND METHODS}

\section{Materials}

Refined, bleached and deodourised (RBD) POs IV30 and POo IV58 were obtained from a local refinery in Malaysia.

\section{Fatty Acid Composition (FAC)}

FAC was determined as fatty acid methyl esters (FAME) according to the procedures described in Noor Lida et al. (2019). FAME was prepared by dissolving $50 \mathrm{mg}$ of a melted and homogenised fat blend in $950 \mu \mathrm{l}$ hexane and $50 \mu \mathrm{l}$ of $1 \mathrm{M}$ sodium methoxide. The mixture was then mixed vigorously with a vortex mixer for $10 \mathrm{~s}$ or until it became cloudy before centrifugation at $2000 \mathrm{rpm}$ for $2 \mathrm{~min}$ to separate the mixture into two distinct layers. The upper clear supernatant consisting of FAME was decanted. One $\mu \mathrm{l}$ of FAME was then injected and analysed using a Hewlett Packard HP 6890 Series (Palo Alto, USA) gas chromatography system equipped with a flame ionisation detector. Separation was performed using a Durabond DB-23 fused silica capillary column (60 m length $\times 0.25 \mathrm{~mm}$ i.e. $x 0.25 \mu \mathrm{m}$ film thickness) (Agilent, Santa Clara, USA). Injector and detector temperatures were set at $240^{\circ} \mathrm{C}$, whereas the column temperature was isothermal at $185^{\circ} \mathrm{C}$. The flow rate of the carrier gas helium was $0.8 \mathrm{ml} \mathrm{min}{ }^{-1}$. Peaks were identified by FAME standards and quantified using the peak area normalisation method. 


\section{Slip Melting Point (SMP)}

SMP of a sample was determined according to the procedures described in MPOB Test Method p4.2:2004 (MPOB, 2004). A molten sample was placed in three capillary tubes $(50-60 \mathrm{~mm}$ length $\mathrm{x}$ 1.1-1.3 mm i.d. x 1.4-1.5 e.d.) with openings at both ends, filling each to a length of $10 \mathrm{~mm}$. The sample in the tube was then solidified by rolling the tube on an ice cube. The capillary tube was then placed in a test tube, and held in a water bath equilibrated at $10^{\circ} \mathrm{C}$ for $16 \mathrm{hr}$. The tube was then attached to a thermometer (graduated in divisions of $0.1^{\circ} \mathrm{C}-0.2^{\circ} \mathrm{C}$ ) with a rubber band, before immersing both into a beaker containing $400 \mathrm{ml}$ of cold distilled water with a temperature of $5^{\circ} \mathrm{C}-10^{\circ} \mathrm{C}$ below the expected SMP of the sample. The water bath was agitated with a magnetic stirrer and heat was applied continuously to increase the bath temperature at a rate of $0.5^{\circ} \mathrm{C}$ $\mathrm{min}^{-1}$. The temperature at which the fat column rose due to hydrostatic pressure was recorded as SMP of the fat sample.

\section{Solid Fat Content (SFC)}

SFC of the oil blend was determined with a Bruker Minispec MQ20 Pulsed Nuclear Magnetic Resonance (p-NMR) analyser (Karlsruhe, Germany) according to the procedures described in MPOB Test Method p4.8:2004-Non-stabilised Serial procedures (MPOB, 2004). A molten sample was filled up to $3 \mathrm{~cm}$ height of a p-NMR tube, re-melted at $70^{\circ} \mathrm{C}$ for 30 min to erase any crystal memory, chilled at $0^{\circ} \mathrm{C}$ for $90 \mathrm{~min}$ and held at the respective measuring temperatures for $30 \mathrm{~min}$ prior to measurement of total solid fat $(\%)$ at each measuring temperature from $5^{\circ} \mathrm{C}-50^{\circ} \mathrm{C}$ at intervals of $5^{\circ} \mathrm{C}$.

The isothermal SFC of vanaspati sample which had been tempered at $25^{\circ} \mathrm{C}$ for $24 \mathrm{hr}$ and $48 \mathrm{hr}$ was also determined with the Bruker Minispec MQ20 p-NMR analyser. The vanaspati was filled up to $3 \mathrm{~cm}$ height of a p-NMR tube and the SFC of the vanaspati was then measured at $25^{\circ} \mathrm{C}$.

\section{Microscopic}

Microscopic examination for fat crystal morphology and distribution in the vanaspati was done by placing a small amount (about 1-10 $\mathrm{mg}$ ) of vanaspati on a glass slide. A glass cover slip was placed on top of the sample and slightly pressed to ensure thin distribution of sample. The sample was immediately viewed under a polarised microscope (Olympus model BH-2, Olympus Corporation, Tokyo, Japan) at room temperature (around $25^{\circ} \mathrm{C}$ ). The microscope was attached to a video camera (Leica Q500mc Qwin Vol 0.02; Leica Cambridge Ltd, Cambridge, United Kingdom) to capture the crystals images. The photomicrograph of the crystal was taken at 100X magnification.

\section{Vanaspati Production}

The vanaspati samples were produced using a blend of POs IV30 and POo IV58 at 40:60 w/w ratio. Blend of POs and POo was used in this study based on previous study by Rustaman et al. (2000) who had successfully produced vanaspati using blend of POs and POo. Minimising types of oils and fats used in a formulation is an effective cost saving option that is preferable in a commercial vanaspati production (Sivaruby and Noor Lida, 2007). Three different process conditions were evaluated as detailed in Table 1. Temperature of $65^{\circ} \mathrm{C}$ was chosen to destroy all memory of crystals in $\mathrm{POo}$ and $55^{\circ} \mathrm{C}$ was chosen to observe the effect of using temperature just around the melting point of POs to start nucleation. Temperature $24^{\circ} \mathrm{C}$ was chosen to represent ambient temperature. Crystallisation of the blend was carried out in a double jacketed $3000 \mathrm{ml}$ vessel with a continuous stirring of $50 \mathrm{rpm}$ speed. Cooling of the fat in the vessel to form vanaspati was carried out using a water bath at a selected controlled temperature. Treatment 1 (VC-1) involved the mixing of POs IV30 at $24^{\circ} \mathrm{C}$ into POo IV58 at $65^{\circ} \mathrm{C}$ and kept mixing the blend to a complete melt at room temperature prior to tempering. Treatment 2 (VC-2) involved the mixing POs IV 30 at $55^{\circ} \mathrm{C}$ into POo IV58 at $24^{\circ} \mathrm{C}$ and continuously mixed to homogeneity at room temperature prior to tempering. Treatment 3 (VC-3) involved the mixing of POs IV 30 at $24^{\circ} \mathrm{C}$ into POo IV58 at $65^{\circ} \mathrm{C}$. In VC-3 treatment, the mixture was not mixed until complete melt, instead, the mixing was stopped once the mixture had formed a slurry. The vanaspati from VC-1, VC-2 and VC-3 treatment were then filled into a $300 \mathrm{ml}$ round shaped plastic containers and tempered at $25^{\circ} \mathrm{C}$ for $24 \mathrm{hr}$ and $48 \mathrm{hr}$.

TABLE 1. THE CRYSTALLISATION TREATMENTS OF PALM STEARIN WITH IODINE VALUE OF 30 (POs IV30) AND PALM OLEIN WITH IODINE VALUE OF 58 (POo IV58) BLEND AT 40:60 W/W RATIO IN THE MAKING OF VANASPATI

\begin{tabular}{cccr}
\hline \multirow{2}{*}{ Treatment } & \multicolumn{2}{c}{ Oil temperature } & Mixing procedure \\
\cline { 2 - 3 } & POs IV30 (40\%) & POo IV58 (60\%) & \\
\hline VC-1 & $24^{\circ} \mathrm{C}$ & $65^{\circ} \mathrm{C}$ & $50 \mathrm{rpm}$, complete mixing /melt, room temperature \\
VC-2 & $55^{\circ} \mathrm{C}$ & $24^{\circ} \mathrm{C}$ & $50 \mathrm{rpm}$, complete mixing /melt, room temperature \\
VC-3 & $24^{\circ} \mathrm{C}$ & $65^{\circ} \mathrm{C}$ & $50 \mathrm{rpm}$, incomplete mixing/melt, slurry form, room temperature \\
\hline
\end{tabular}




\section{RESULTS AND DISCUSSION}

\section{Characteristics of the Vanaspati Oil Blend}

The FAC and SFC profile of the blends of POs IV30 and POo IV58 at 40:60 w/w ratio, having SMP of $47^{\circ} \mathrm{C}$ and IV of 47.95 are shown in Table 2 and Figure 1, respectively. The blend consisted of $53.36 \%$ saturated, $37.50 \%$ monounsaturated and 9.02\% polyunsaturated fatty acids. The major fatty acids were palmitic and oleic acids with significant amount of linoleic and stearic acids. The SFC at the application and storage temperatures of $25^{\circ} \mathrm{C}-40^{\circ} \mathrm{C}$ ranged from $24 \%$ at $25^{\circ} \mathrm{C}$ to $12 \%$ at $40^{\circ} \mathrm{C}$. Hence, this blend has the potential to remain solid at this temperature range, which is also the crucial temperature of storage that ranges from $25^{\circ} \mathrm{C}-40^{\circ} \mathrm{C}$.

TABLE 2. FATTY ACID COMPOSITION (\%) OF THE BLENDS OF PALM STEARIN WITH IODINE VALUE OF 30 (POs IV30) AND PALM OLEIN WITH IODINE VALUE OF 58 (POo IV58) AT 40:60 W/W RATIO

\begin{tabular}{lc}
\hline Fatty acids & Composition (\%) \\
\hline Lauric acid (C12:0) & $0.21 \pm 0.02$ \\
Myristic acid (C14:0) & $1.10 \pm 0.00$ \\
Palmitic acid (C16:0) & $47.34 \pm 0.02$ \\
Palmitoleic acid (C16:1) & $0.17 \pm 0.00$ \\
Stearic acid (C18:0) & $4.39 \pm 0.00$ \\
Oleic acid (C18:1 n9t) & $0.00 \pm 0.00$ \\
Oleic acid (C18:1 n9c) & $37.33 \pm 0.02$ \\
Oleic acid (C18:1 n9ci) & $0.00 \pm 0.00$ \\
Linoleic acid (C18:2n6t) & $0.12 \pm 0.00$ \\
Linoleic acid (C18:2n6c) & $8.82 \pm 0.00$ \\
Linolenic acid (C18:3) & $0.20 \pm 0.00$ \\
Arachidic acid (C20:0) & $0.32 \pm 0.01$ \\
Total saturated fatty acid & $53.36 \pm 0.02$ \\
Total monounsaturated fatty acid & $37.50 \pm 0.02$ \\
Total polyunsaturated fatty acid & $9.02 \pm 0.00$ \\
\hline
\end{tabular}

The SFC of the vanaspati produced using VC-1 treatment which was tempered at $25^{\circ} \mathrm{C}$ for $24 \mathrm{hr}$ and $48 \mathrm{hr}$ is shown in Table 3. The SFC of the vanaspati after $24 \mathrm{hr}$ and $48 \mathrm{hr}$ of tempering were $20.95 \%$ and $21.71 \%$, respectively, showing that there was no drastic increase in SFC between 24-48 hr of tempering at $25^{\circ} \mathrm{C}$. The SFC of the vanaspati VC- 1 after $48 \mathrm{hr}$ of tempering was lesser by $2.69 \%$ than the SFC of the oil blend at $25^{\circ} \mathrm{C}(24.4 \%$, Figure 1$)$. These results indicated that crystal growth was very effective during production of the palm-based vanaspati using the VC-1 treatment.

TABLE 3. SOLID FAT CONTENT (SFC) OF VANASPATI MADE OF PALM STEARIN WITH IODINE VALUE OF 30 (POs IV30) AND PALM OLEIN WITH IODINE VALUE OF 58 (POo IV58) AT 40:60 W/W RATIO AFTER TEMPERING AT $25^{\circ} \mathrm{C}$ FOR 24 HR AND 48 HR

\begin{tabular}{cccc}
\hline \multirow{2}{*}{$\begin{array}{c}\text { Tempering } \\
\text { time (hr) }\end{array}$} & \multicolumn{3}{c}{ SFC (\%) } \\
\cline { 2 - 4 } & Vanaspati & Vanaspati & Vanaspati \\
& VC-1 & VC-2 & VC-3 \\
\hline 24 & 20.95 & 18.93 & 10.40 \\
48 & 21.71 & 19.21 & 11.36 \\
\hline
\end{tabular}

When POs IV30 at $24^{\circ} \mathrm{C}$ was added into POo IV58 at $65^{\circ} \mathrm{C}$, the low melting TAG (with SMP of less than $65^{\circ} \mathrm{C}$ ) of the POs IV30 melted. However, some high melting TAG primarily tripalmitin (PPP) were not melted. As the fat was cooled to $24^{\circ} \mathrm{C}$, the high melting TAG became the centre of crystallisation creating big crystal agglomerates. The crystal morphology of vanaspati VC-1 at $24 \mathrm{hr}$ and $48 \mathrm{hr}$ is shown in Figure 2. Theoretically, when bulk oil is crystallised, the entire mass does not crystallise at the same time, but crystallisation begins at discrete sites when the temperature reaches a level that creates crystallisation nuclei (Lawler and Dimick, 2008; De Oliveira; et al., 2015). The time for the whole bulk to crystallise depends on the rate of interaction between the crystallised fats and the neighbouring liquid



Figure 1. Solid fat content of the blend of palm stearin with iodine value of 30 (POs IV30) and palm olein with iodine value of 58 (POo IV58) at 40:60 w/w ratio. 
phase (Normah, et al., 2013). The crystallisation pattern is also influenced by the parameter setting of agitation. The VC-1 treatment was able to produce discrete crystal structures. The addition of POs IV30 at $24^{\circ} \mathrm{C}$ into POo IV58 at $65^{\circ} \mathrm{C}$ was able to induce slow nucleation with nuclei that were able to create discrete crystals. There was no major change observed in crystal morphology after $24 \mathrm{hr}$ as discrete crystals in liquid oil was observed. Figure 3 shows coarseness of the blend's texture after $48 \mathrm{hr}$ of tempering. This observation complemented the morphology of the coarse crystals observed by the microscope (Figure 2). The coarse crystals morphology is normally observed in granular type vanaspati. Thus, VC-1 treatment on the blend of POs IV30 and POo IV58 at 40:60 w/w ratio is recommended for the production of granular type vanaspati.

The SFC of vanaspati produced using VC-2 treatment which was tempered at $25^{\circ} \mathrm{C}$ for $24 \mathrm{hr}$ and $48 \mathrm{hr}$ is shown in Table 3. The SFC of vanaspati after tempering for $24 \mathrm{hr}$ and $48 \mathrm{hr}$ were $18.93 \%$ and $19.21 \%$, respectively, showing no drastic increase in the SFC between $24-48 \mathrm{hr}$ of tempering. The SFC of vanaspati VC-2 after $48 \mathrm{hr}$ of tempering was lesser by $5.19 \%$ than the SFC of the oil blend at $25^{\circ} \mathrm{C}(24.4 \%$, Figure 1) and was $2.5 \%$ lesser than that of vanaspati VC-1 $(21.71 \%)$. These observations denoted that less

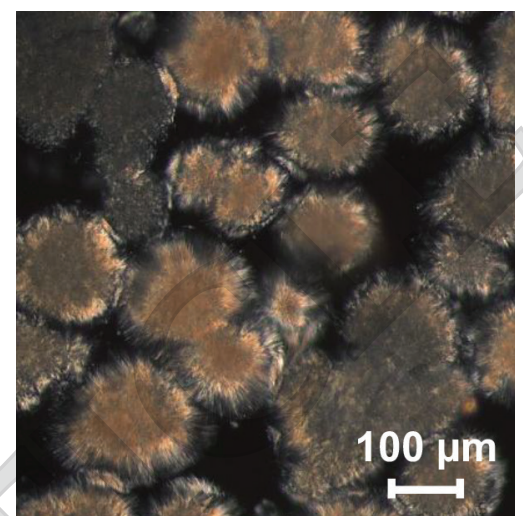

(a) liquid was entrapped into the crystal matrix, hence, resulted in lower SFC than vanaspati VC-1 and the oil blend. The results also indicated that VC-2 treatment produced lesser crystal development as shown by the low SFC $(18.93 \%)$ at $25^{\circ} \mathrm{C}$, indicating that crystallisation could be less efficient as compared to VC-1 treatment.

Figure 4 shows the crystal morphology of vanaspati VC-2 after $24 \mathrm{hr}$ and $48 \mathrm{hr}$ of tempering at $25^{\circ} \mathrm{C}$. The addition of POs IV30 with temperature of $55^{\circ} \mathrm{C}$ into POo IV58 of temperature $24^{\circ} \mathrm{C}$ induced fast nucleation. The fast nucleation was caused by rapid drop of temperature of POs IV30 from $55^{\circ} \mathrm{C}$ to $24^{\circ} \mathrm{C}$. The instant inducement of nuclei produced large number of nucleus, which in turn produced small crystals during tempering at $25^{\circ} \mathrm{C}$ as shown in Figure 4. Discrete crystal structure such as observed in vanaspati VC-1 was not detected in vanaspati VC-2. There was no major change observed in crystal morphology between 24-48 hr of tempering. Figure 5 shows the smooth texture of vanaspati VC-2 after $48 \mathrm{hr}$ of tempering. The texture of vanaspati VC-2 complemented the crystals morphology by the microscope. Thus, VC-2 treatment on the blend of POs IV30 and POoIV58 at 40:60 w/ w ratio produced small crystals which is suitable for the production of smooth textured vanaspati.

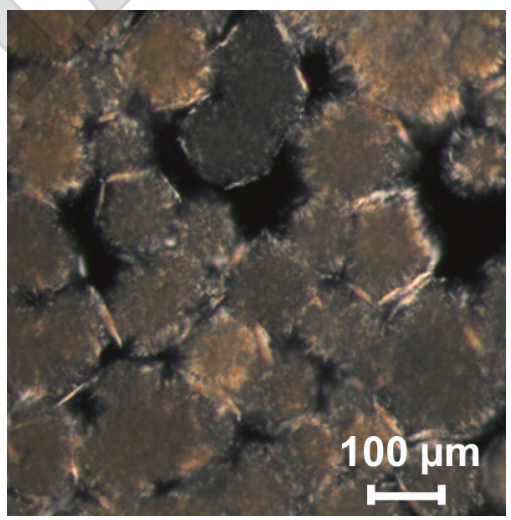

(b)

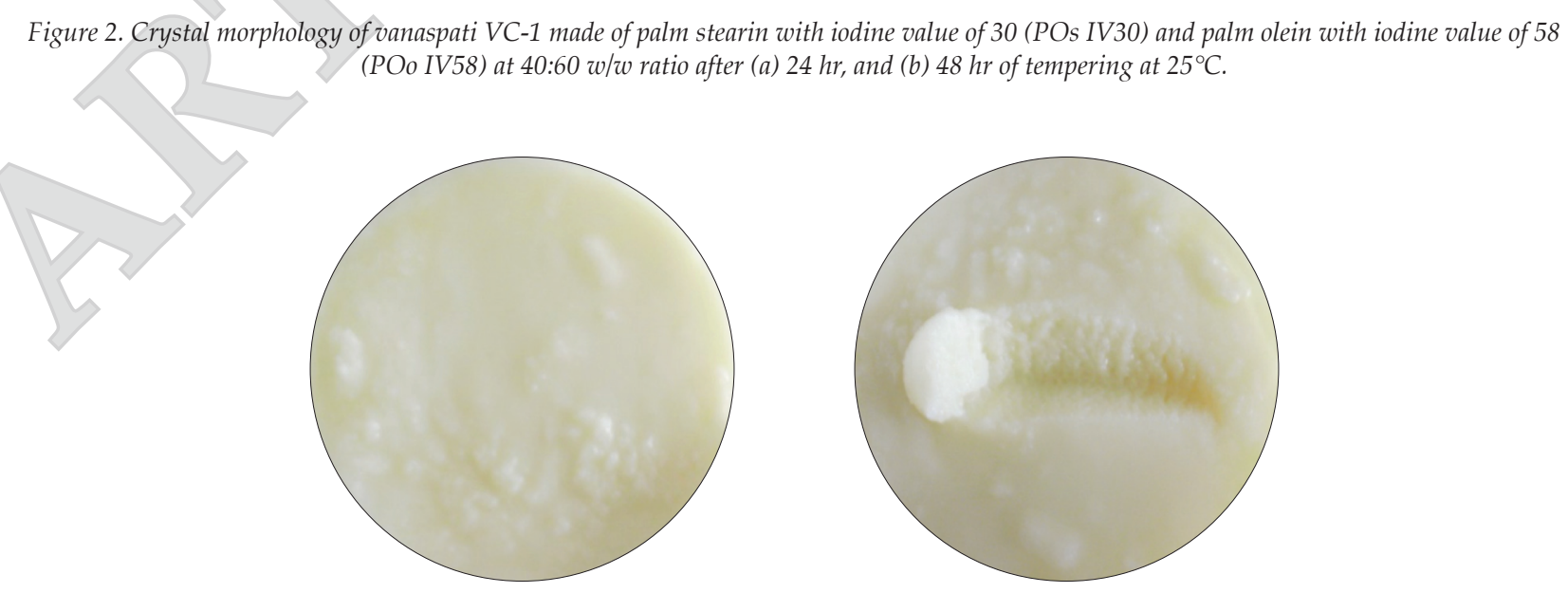

Figure 3. Physical appearance of vanaspati VC-1 made of palm stearin with iodine value of 30 (POs IV30) and palm olein with iodine value of 58 (POo IV58) at 40:60 w/w ratio after $48 \mathrm{hr}$ of tempering at $25^{\circ} \mathrm{C}$. 


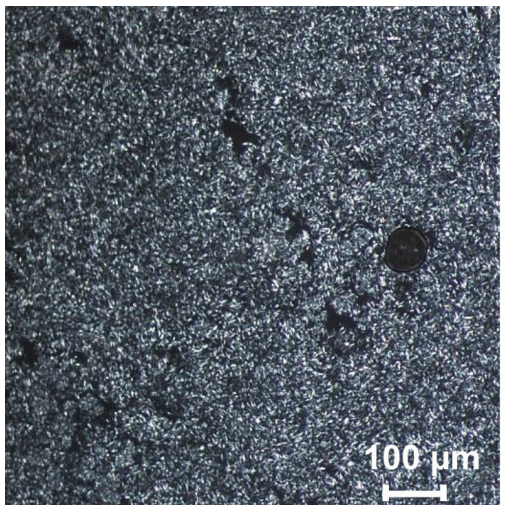

(a)

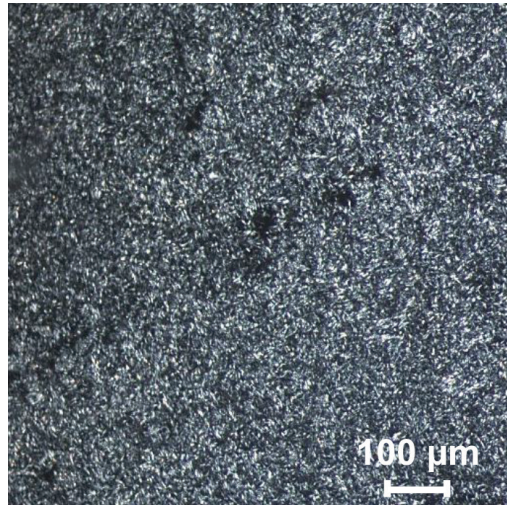

(b)

Figure 4. Crystal morphology of vanaspati VC-2 made of palm stearin with iodine value of 30 (POs IV30) and palm olein with iodine value of 58(POo IV58) at 40:60 w/w ratio after (a) $24 \mathrm{hr}$ and (b) $48 \mathrm{hr}$ of tempering at $25^{\circ} \mathrm{C}$.
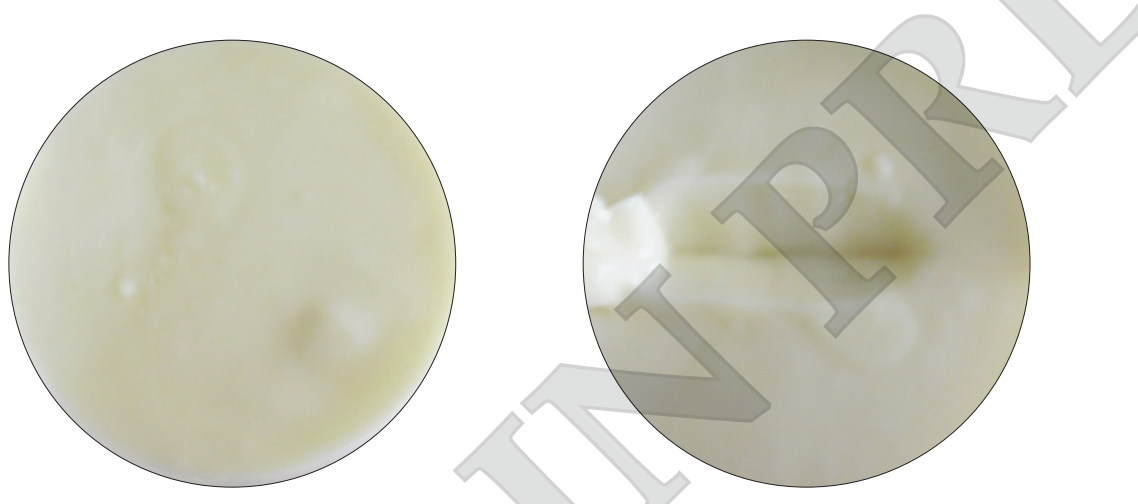

Figure 5. Physical appearance of vanaspati VC-2 made of palm stearin with iodine value of 30 (POs IV30) and palm olein with iodine value of 58 (POo IV58) at 40:60 w/w ratio after $48 \mathrm{hr}$ of tempering at $25^{\circ} \mathrm{C}$.

The SFC of vanaspati produced using VC-3 treatment after tempering at $25^{\circ} \mathrm{C}$ for $24 \mathrm{hr}$ and $48 \mathrm{hr}$ were $10.40 \%$ and $11.36 \%$, respectively (Table 3), denoting only a slight increase in the SFC between $24-48 \mathrm{hr}$ of tempering at $25^{\circ} \mathrm{C}$. The SFC obtained after $48 \mathrm{hr}$ of tempering was lesser by $13.04 \%$ than the SFC of the oil blend at $25^{\circ} \mathrm{C}(24.4 \%$, Figure 1$)$. The SFC of vanaspati VC-3 was also lesser than that of vanaspati VC-1 (10.35\% less) and vanaspati VC-2 (7.85\% less). These observations denoted that only approximately $50 \%$ of the oil blend crystalised and $50 \%$ remained in liquid state. In order for a crystal to entrap liquid oil in its structure, the crystal should form (starting from nucleation) and grow from a liquid state until it reaches stabilisation state. In VC-3 treatment, the POs IV30 which was already in crystallised form was not fully melted when it was mixed with the POo IV58 of $65^{\circ} \mathrm{C}$. The mixture was not homogenised and was kept in slurry form prior to tempering at $25^{\circ} \mathrm{C}$. Hence, the crystals were not able to entrap the liquid oil within the crystal matrix at $25^{\circ} \mathrm{C}$, thus, resulted in lower $\mathrm{SFC}$.

Figure 6 shows the crystal morphology of vanaspati VC-3 at $24 \mathrm{hr}$ and $48 \mathrm{hr}$ of tempering at $25^{\circ} \mathrm{C}$. Although, the temperature treatment of VC-3 was similar to VC-1 treatment, VC-3 treatment did not produce big crystal agglomerations. In VC-3 treatment, the low melting TAG of the POs IV30 were not completely melted. The slurry mixture of POs IV30 and POo IV58 contained a huge amount of crystals (high and low melting TAG) that acted as nuclei, thus, crystallisation was not focussed to small number of sites but had taken place in a big number of crystallisation sites. The crystals experienced only limited growth. This situation resulted in formation of small crystals which were more in number and loosely packed as compared to the crystals formed in vanaspati produced using VC-1 treatment. The small crystals and loosely packed structure led to the formation of a slightly grainy texture. There was no major change observed in crystal morphology between 24-48 hr. Discrete crystal structure such as observed in vanaspati VC-1 was not detected in vanaspati VC-3. Based on the crystal morphology, vanaspati VC-3 had smaller crystals and denser than vanaspati VC-1, but its crystals were bigger and less dense than vanaspati VC-2. Figure 7 shows the texture of the blend after $48 \mathrm{hr}$ of tempering. This observation complemented the morphology of crystals observed by the microscope. Hence, VC-3 treatment is recommended for the production of vanaspati with slightly grainy texture. 


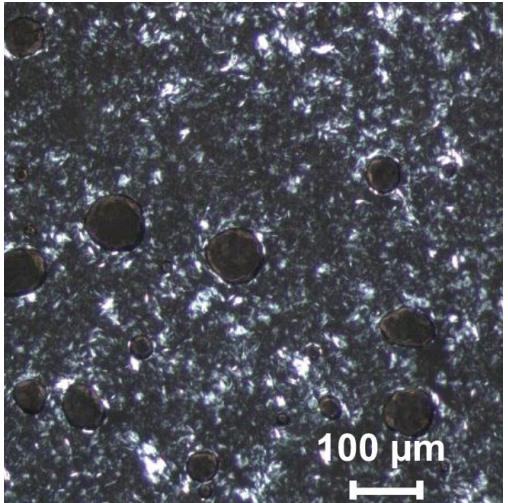

(a)

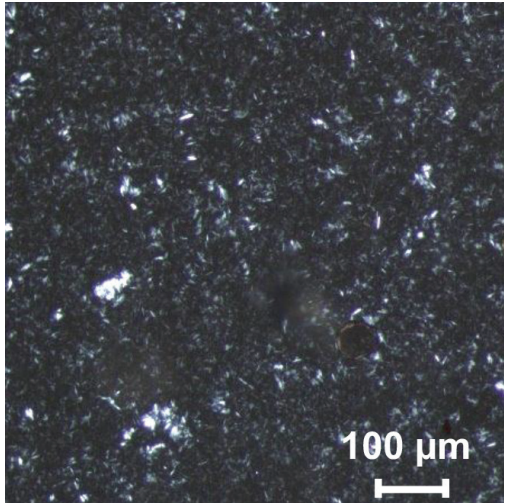

(b)

Figure 6. Crystal morphology of vanaspati VC-3 made of palm stearin with iodine value of 30 (POs IV30) and palm olein with iodine value of 58 (POo IV58) at 40:60 w/w ratio after (a) $24 \mathrm{hr}$ and (b) $48 \mathrm{hr}$ of tempering at $25^{\circ} \mathrm{C}$.
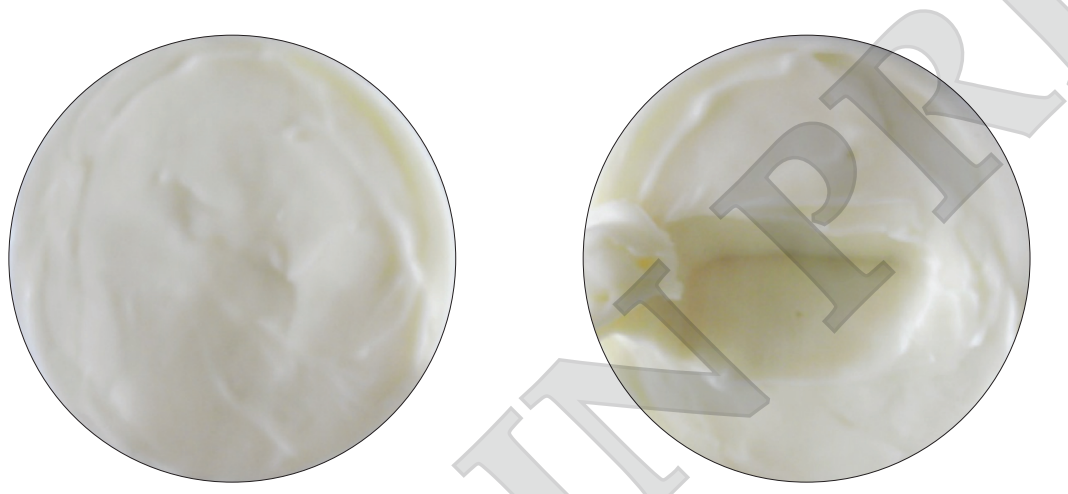

Figure 7. Physical appearance of vanaspati VC-3 made of palm stearin with iodine value of 30 (POs IV30) and palm olein with iodine value of 58 (POo IV58) at 40:60 w/w ratio after $48 \mathrm{hr}$ of tempering at $25^{\circ} \mathrm{C}$.

\section{CONCLUSION}

VC-1 treatment which involved mixing of POs IV30 at $24^{\circ} \mathrm{C}$ into POo IV58 at $65^{\circ} \mathrm{C}$ and mixing the blend to a complete melt at room temperature followed by tempering at $25^{\circ} \mathrm{C}$ produced a granulated vanaspati with spherical or granular shape crystals. VC-2 treatment which involved the mixing of POs IV30 at $55^{\circ} \mathrm{C}$ into POo IV58 at $24^{\circ} \mathrm{C}$ and mixing the blend to a complete melt at room temperature followed by tempering at $25^{\circ} \mathrm{C}$ produced small crystals which is suitable for the production of smooth textured vanaspati. Vanaspati produced using VC-3 treatment which involved the mixing of POs IV 30 at $24^{\circ} \mathrm{C}$ into POo IV58 at $65^{\circ} \mathrm{C}$ but was not mixed to complete melt, followed by tempering at $25^{\circ} \mathrm{C}$ produced small crystals and loosely packed structure which led to the formation of a slightly grainy textured vanaspati.

\section{ACKNOWLEDGEMENT}

The authors thank the Director-General of MPOB for permission to publish this article. The authors also thank Dr Miskandar Mat Sahri for his expert advice and the staff of Food Technology Group for their skilful technical assistance in ensuring the success of this study.

\section{REFERENCES}

Ahmad, W; Mustafa, K and Ahmad, T (2006). Factors influencing customer's preference for purchase of vegetable ghee: A comparison of two 'ghee firms' in Punjab. Pakistan J. Agricultural Sciences, 43: 1-2.

Blaurock, A E (1999). Fundamental understanding of the crystallisation of oils and fats. Physical Properties of Fats, Oils and Emulsifiers (Widlak, N ed.). AOCS Press, Champaign, IL, USA. p. 1-30.

De Oliveira, G M; Ribeiro, A P B; dos Santos, A O; Cardoso, L P and Kieckbusch, T G (2015). Hard fats as additives in palm oil and its relationships to crystallization process and polymorphism. LWTFood Science and Technology, 63(2): 1163-1170.

Farmani, J and Gholitabar, A (2015). Characterization of vanaspati fat produced in Iran. J. Amer. Oil Chem. Soc., 92(5): 709-716. 
Farmani, J; Hamedi, M; Safari, M and Madadlou, A (2007). Trans-free Iranian vanaspati through enzymatic and chemical transesterification of triple blends of fully hydrogenated soybean, rapeseed and sunflower oils. Food Chemistry, 102(3): 827-833.

Garti, N (2002). Food emulsifiers: Structure-reactivity relationships, design and applications. Physical Properties of Lipids. CRC Press. p. 268-389.

Herrera, M L and Hartel, R W (2000). Effect of processing conditions on crystallization kinetics of a milk fat model system. J. Amer. Oil Chem. Soc., 77(11): 1177-1188.

Kheiri, M S A (1985). Palm oil products in cooking fats. J. Amer. Oil Chem. Soc., 62(2): 410-416.

Kheiri, M S A and Oh, F C (1983). Formulation of vegetable ghee/vanaspati. Palm Oil Product Technology in the Eighties. p. 449-468.

Lawler, P J and Dimick, P S (2008). Crystallization and polymorphism of fats. Food Lipids $3^{\text {rd }}$ Edition (Casmir, C A and David, B M ed.). CRC Press, Florida, USA. p. 245-267.

Martini, S; Herrera, M L and Hartel, RW (2002). Effect of cooling rate on crystallization behavior of milk fat fraction/sunflower oil blends. J. Amer. Oil Chem. Soc., 79(11): 1055-1062.

Miskandar, M S; Che Man, Y B; Yusoff, M S A and Abdul Rahman, R (2002a). Effect of emulsion temperature on physical properties of palm oil-based margarine. J. Amer. Oil Chem. Soc., 79(12): 1163-1168.

Miskandar, M S; Che Man, Y B; Yusoff, M S A and Abdul Rahman, R (2002b). Effect of scraped-surface tube cooler temperature on physical properties of palm oil margarine. J. Amer. Oil Chem. Soc., 79(9): 931936.

Miskandar, M S; Che Man, Y B; Yusoff, M S A and Abdul Rahman, R (2004). Palm oil crystallization: Effects of cooling time and oil content. J. Food Lipids, 11(3): 190-207.

MPOB (2004). A compendium of test on palm oil products, palm kernel products, fatty acids, foodrelated products and others. MPOB Test Method. MPOB, Bangi.

Normah, I; Cheow, C S and Chong, C L (2013). Crystal habit during crystallization of palm oil: Effect of time and temperature. Int. Food Research J., 20(1).

Noor Lida, H M D; Lee, Y Y; Nik Aznizan, N I; Norazura Aila, M H; Saw, M H; Tan, CP and Lai, O M
(2019). Low-temperature directed interesterification increases triunsaturated and trisaturated triacylglycerols of palm oil and affects its thermal, polymorphic and microstructural properties. J. Oil Palm Res. Vol. 31(1): 95-109.

Noor Lida, H M D; Rafidah, A H; Sivaruby, K; Wan Rosnani, A I; Norazura Aila, M H; Nurhaqim, I; Zaliha, O and Miskandar, M S (2017). Palm oil and palm kernel oil: Versatile ingredients for food applications. J. Oil Palm Res. Vol. 29(4): 487-511.

Nor Aini, I; Hanirah, H; Maimon, C H; Zawiah, S and Che Man, Y B (2010). Physico-chemical properties and quality of palm-based vegetable ghee. Sains Malaysiana, 39(5): 791-794.

Nor Aini, I and Noor Lida, HMD(2005). Interesterified palm products as alternatives to hydrogenation. Asia Pacific J. Clinical Nutrition, 14(4): 396-401.

Nor Aini, I; Che Maimon, C H; Hanirah, H; Zawiah, S and Che Man, Y B (1999). Trans-free vanaspati containing ternary blends of palm oil-palm stearinpalm olein and palm oil-palm stearin-palm kernel olein. J. Amer. Oil Chem. Soc., 76(5): 643-648.

Nor Aini, I; Mohd Suria Affandi, Y and Mohd Arif, S (1997). Palm-based trans free vanaspati. PORIM Information Series No. 66. MPOB, Bangi.

NPCS (2020). Vanaspati ghee industry. NIR Project Consultancy Services (NPCS) Report on https:// www.entrepreneurindia.co/blog-description / 6836/ vanaspati +ghee+industry, accessed on 25 March 2020.

Rustaman, A; Muchtadi, T R and Adawiyah, D R (2000). Vegetable ghee formulation with blending technique from palm olein and palm stearin fraction. Prosiding Seminar Nasional Industri Pangan, Surabaya (Indonesia). 10-11 October 2000. Perhimpunan Ahli Teknologi Pangan Indonesia.

Siew, W L (2011). Palm oil. Vegetable Oils in Food Technology: Composition, Properties and Uses (Gunstone, F D ed.). John Wiley \& Sons Ltd., West Sussex, United Kingdom. p. 25-54.

Sivaruby, Kand Noor Lida, H MD (2007). Maximizing the use of palm stearin in vegetable ghee (Vanasapati). Proc. of the PIPOC 2007 International Palm Oil Congress - Product Development and Nutrition Conference. MPOB, Bangi.

Tanaka, L; Miura, S and Yoshioka, T (2007). Formation of granular crystals in margarine with excess amount of palm oil. J. Amer. Oil Chem. Soc., 84(5): 421-426. 